\title{
Prevalence of $H$. pylori strains harbouring cagA and ice $A$ virulence genes in saudi patients with gastritis and peptic ulcer disease
}

\author{
Roqayah H. Kadi ${ }^{1}$, Eman M. Halawani ${ }^{1}$ and Hayam S. Abdelkader ${ }^{2 *}$ \\ *Correspondence: hayamabdelkader68@yahoo.com

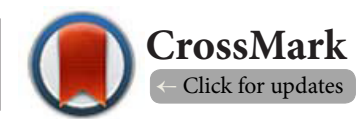 \\ ${ }^{1}$ Biology Department, Faculty of Science, Taif University, Kingdom of Saudi Arabia. \\ ${ }^{2}$ Biotechnology Department, Faculty of Science, Taif University, Kingdom of Saudi Arabia.
}

\begin{abstract}
Aim: The study is aimed to detect the presence of $\operatorname{cag} A$, ice $A 1$, and iceA2 virulence genes in $H$. pylori from gastric biopsies, and to deduce the correlation between these genotypes and the two clinical outcomes peptic ulcer disease (PUD), and gastritis.

Materials and methods: Thirty three Saudi patients 15 males and 18 females, 20 to 90 years were assigned into two groups PUD and gastritis. Genomic DNAs were extracted from biopsy specimens and used to detect the presence of cagA, and iceA genes by PCR typing system. Fisher's and Phi coefficient association tests were used for statistical analysis.

$\underline{\text { Results: }}$ Genotyping show that both cagA and iceA genes were amplified from 27 specimens (81.7\%). The prevalence of $c a g A+$ and cagA-genotypes or ice $A+$ and ice $A$ - genotypes did not differ significantly between males and females $(p=0.070)$. Within the PUD and gastritis groups, the percentages of specimens positive for cagA gene were $76.9 \%$ and $85 \%$, while those positive for $i c e A+$ were $92.3 \%$ and $75 \%$ respectively. All cagA+/ice $A+$ combined genotypes was statically correlated with peptic ulcer (77\%). This correlation was not observed within $H$. pylori specimens typed from gastritis. Patients with either PUD or gastritis were most likely infected by several strains of $H$. pylori.

Conclusion: Different strains of $H$. pylori have virulent genotypes evidenced by PCR-based genotyping from biopsy specimens at a reasonable cost and time. These virulence strains spread at Taif province, may result in sever clinical outcomes such as ulcers which may be developed to cancer, the situation which necessitates further studies.
\end{abstract}

Keywords: H. pylori, cagA genotype, iceA+ genotype, peptic ulcer, gastritis, PCR-based genotyping, gastric biopsies

\section{Introduction}

Helicobacter pylori colonizing the human stomach acquired by contaminated water or food or poorly disinfected endoscopes. Lifetime persistence of this organism within the host could result in a number of gastroduodenal diseases ranging from mild gastritis, atrophic gastritis, and peptic ulcer disease to malignant diseases such as gastric adenocarcinoma and Mucosa-Associated-Lymphoid-Tissue (MALT) Lymphoma [1,2].

Although a chronic active gastritis will be developed by most of infected patients, the majorities of infections are asymptomatic [1-3]. Found that, $15-20 \%$ of infected patients will develop gastric or duodenal ulcer disease and less than $1 \%$ will develop gastric adenocarcinoma. Due to poor correlation between symptoms and disease, many of gastric cancer cases are detected lately when the disease is rooted and become incurable. Direct PCR methods performed on H. pylori DNA isolated from biopsy specimens have been evaluated previously [4-7].

In developing countries, $H$. pylori infection is particularly high (up to 80\%) [9-11]. The prevalence of H. pylori infection in Jordan and Bahrain was $77.5 \%$ and $79 \%$, respectively $[12,13]$. In Kuwait and Egypt, H. pylori were present in $84 \%$ and $86 \%$ of the biopsy samples, respectively $[\mathbf{1 4}, \mathbf{1 5}]$ while the rate of infections reached $87 \%$ in the Eastern region and $61.6 \%$ in Central and Western region in the Kingdom of Saudi Arabia $[16,17]$. Although some studies have reported an excess of $H$. pylori in one gender versus the other $[18,19]$, found no gender differences in H. pylori prevalence overall.

Over the past few years, research on pathogenicity markers has become gradually more important and intense in an attempt to detect bacterial strains associated with each of these diseases. The cytotoxin-associated gene A (cagA gene) was the first virulence factor detected in $H$. pylori strains. This gene encodes a protein that is associated with an increase in intensity of gastric inflammation and, consequently, with severe clinical outcomes, inducing an intense inflammatory process, with dense neutrophil infiltration, which can cause serious hurt to the gastric mucosa. The induced by contact with epithelium (iceA) gene has two allelic forms, ice $A 1$ and iceA2 $[18,19]$.

The expression of iceA1 was controlled by contact between H. pylori and human epithelial cells [20] and the iceA1 genotype was associated with enhanced mucosal interleukin (IL)-8 expression and acute antral inflammation [21].

Although iceA gene has no correlation with gastric cancer

(c) 2014 Abdeikader et al; licensee Herbert Publications Ltd. This is an Open Access article distributed under the terms of Creative Commons Attribution License (http://creativecommons.org/licenses/by/3.0). This permits unrestricted use, distribution, and reproduction in any medium, provided the original work is properly cited. 
Kadi et al. Microbiology Discovery 2014,

development, there is an inconclusive argument about the role of this gene in gastric pathology. Although $[20,22]$, proved the role of iceA 1 allele in peptic ulcer, others did not find any role for this allele in gastroduodenal disease [22] while, [23] reported an inverse association between the ice $A 2$ allele and peptic ulcer.

Several studies were not able to explain the role of iceA and its correlation with clinical outcomes in other populations; therefore the mechanism of how iceA induce PUD remains unclear $[\mathbf{2 4}, \mathbf{2 5}]$. Such contradicted results between the ice $A$ genotype and clinical consequences could be explicated by the genetic diversity or differences in the geographic region, which were previously reported for other virulence factors [26]. Moreover, geographic variations in addition to genetic heterogeneity of the host further contribute to the diversity of host responses to particular $H$. pylori strains and genotypes [27].

The objectives of current study are to detect the virulence genes (cagA, ice $A 1$ and iceA2) by polymerase chain reaction (PCR) in gastric biopsy specimens and to find out the possible association between these virulence genotypes and the clinical outcomes.

\section{Subjects and methods Sample collection}

Thirty three biopsy specimens were collected from 15 males and 18 females attending the endoscopy clinic at three hospitals; King Faisal, AL Hada Armed Forces, and King AbdulAziz in Taif province, Kingdome of Saudi Arabia between September 2011 and February 2012. Mean age $( \pm 47)$ was varying from 20 to 90 years. These patients were scheduled for gastroscopy by their physician based on various symptoms such as abdominal pain, reflux and dyspepsia.

The study was approved by the ethics committee of Taif University and each hospital has obtained an informed consent from each patient prior to performing the study.

The gastric biopsies were transferred immediately into sterile tubes containing $3 \mathrm{ml}$ of saline or Brucella broth labeled with the patient's I.D. and date. Samples were brought directly to the lab for immediate processing. Campylobacter-like organism(CLO) test was done on the 33 mucosal specimens. Patients were assigned in the following groups based on the gastroenterologist's diagnosis:

1. PUD group: when there was evidence of erosion or ulceration in the gastric mucosa with exudates and erythema.

2. Gastritis group: when there was evidence of inflammation, edema, punctuate hemorrhage, friability, or nodularity.

The biopsy specimens were fragmented using a sterile pestle and mortar. Further homogenization was done by passing the lysate alternatively 5 times through a $0.9 \mathrm{~mm}$ needle (20 gauges) fitted to a syringe. The resulting lysate was divided into aliquots and placed into a microcentrifuge tube for DNA extraction.

\section{Genomic DNA isolation}

Genomic DNAs were extracted from thirty three biopsy specimens using the QIAamp DNA mini kit (Qiagen $\mathrm{GmbH}$, Hilden, Germany), as described by the manufacturer. The tissue biopsies were centrifuged at $5000 \mathrm{xg}$ for $10 \mathrm{~min}$ and re-suspended in $200 \mu \mathrm{l}$ of ATL buffer (supplied in the QIAamp DNA Mini Kit) for complete lysis. Finally, the DNAs were eluted in $100 \mu \mathrm{L}$ of elution buffer. DNA purity and quantity was determined using a GeneSys 10UV spectrophotometer (Thermo Scientific, USA).

\section{Genotyping-PCR}

Isolated genomic DNAs (gDNAs) were used to detect the presence of cagA, and iceA by PCR. Primers used for cagA gene amplification were as follows: forward primer cagA F1 (5'-GATAACAGCCAAGCTTTTGAGG-3') and reverse primer cagA B1 (5'-CTGCAAAAGATTGTTTGGCAGA-3') to amplify 349 bp fragment; cagA F2( 5'-AATACACCAACGCCTCCAAG-3') and cagA B2 (5'-TTGTTGCCGCTTGCTCTC-3') to amplify $400 \mathrm{bp}$ fragment. The primers used for ice $A 1$ amplification were iceA1F(5'- GTGTTTTTAACCAAAGTATC-3') and iceA1 R (5'-CTATAGCCASTYTCTTTGCA-3') to amplify 247 bp; and iceA2 amplification; iceA2 F (5'-GTTGGGTATATCACAATTTAT-3') and iceA2 R (5'- TTRCCCTATTTTCTAGTAGGT-3') to amplify either 229 or 334 bp depending on the number of 105-bp repeated insertions. Each PCR reaction was carried out in a final volume of $25 \mu$ as follows: cagA: $13 \mu \mathrm{l}$ of molecular grade water (Qiagen), 1X PCR buffer (Qiagen), $200 \mu \mathrm{M}$ dNTPs (Qiagen), $0.6 \mu \mathrm{M}$ primers, $1.5 \mathrm{mM} \mathrm{MgCl}{ }_{2}$ (Qiagen), $0.25 \mathrm{U}$ of Taq DNA polymerase (Qiagen) and $2.5 \mu \mathrm{l}$ of DNA. iceA1 and/or iceA2: $13 \mu \mathrm{l}$ of molecular grade water (Qiagen), 1X PCR buffer (Qiagen), $200 \mu \mathrm{M}$ dNTPs (Qiagen), $0.6 \mu \mathrm{M}$ of each forward and reverse primer, $1.5 \mathrm{mM} \mathrm{MgCl}$ (Qiagen), $0.25 \mathrm{U}$ of Taq DNA polymerase (Qiagen) and $2.5 \mu$ of DNA. DNA fragments were visualized by UV transillumination(Biometra, $\mathrm{GmbH}$, Germany).

\section{Statistical analysis}

Fisher's exact and Phi coefficient association tests were used for analysis of two-by-two and two-by-four- tables of categorical data. All tests were two-tailed, and the significance level was assumed as 0.05 .

\section{Results}

The distribution of cagAt, and cagA- genotypes within collected samples is shown in (Table 1 and Figure 1). The PCR-based amplification showed that 27 cases (81.7\%) were cagA+, while 6 cases $(18.8 \%)$ were cagA-. The percentages of cagA+ were $77 \%$ (10/13) and $85 \%$ (17/20) for PUD and gastritis cases, respectively. The percentage of cagA+ genotype within each clinical outcome was significantly higher than that of cagA- genotype $(p<0.001)$. However, the prevalence of $\operatorname{cag} A+$ and $\operatorname{cag} A-$ genotypes did not differ significantly between the two clinical 
Kadi et al. Microbiology Discovery 2014,

Table 1. Prevalence of $\boldsymbol{H}$. pylori genotypes detected in 33 gastric biopsy specimens enrolled in the current study.

\begin{tabular}{|c|c|c|c|c|c|}
\hline Samples No. & $\operatorname{cag} A$ & iceA1 & iceA2 & gender & diagnosis \\
\hline $\mathrm{A} 1$ & + & + & + & $\mathrm{M}$ & PUD \\
\hline A2 & - & - & + & $\mathrm{F}$ & PUD \\
\hline A3 & + & + & + & M & PUD \\
\hline A4 & - & - & - & M & G \\
\hline A5 & + & + & + & $\mathrm{F}$ & PUD \\
\hline A6 & + & + & + & $\mathrm{F}$ & G \\
\hline A7 & + & + & + & $\mathrm{F}$ & PUD \\
\hline A8 & + & + & + & $\mathrm{F}$ & G \\
\hline A9 & + & + & + & M & G \\
\hline A10 & + & + & + & M & G \\
\hline A11 & + & + & + & $\mathrm{F}$ & PUD \\
\hline A12 & + & + & + & $\mathrm{F}$ & G \\
\hline A13 & + & + & + & $\mathrm{F}$ & G \\
\hline $\mathrm{F} 1$ & - & + & - & M & G \\
\hline $\mathrm{F} 2$ & + & - & - & M & G \\
\hline F3 & - & + & + & $\mathrm{F}$ & PUD \\
\hline $\mathrm{F} 4$ & + & + & + & $\mathrm{F}$ & PUD \\
\hline F5 & + & + & + & M & PUD \\
\hline F6 & + & + & + & $\mathrm{F}$ & PUD \\
\hline F7 & + & - & + & M & G \\
\hline F8 & - & - & - & $\mathrm{M}$ & PUD \\
\hline F9 & + & + & + & $\mathrm{F}$ & G \\
\hline F10 & + & - & + & $\mathrm{F}$ & G \\
\hline F11 & + & - & + & $\mathrm{F}$ & G \\
\hline F12 & + & + & + & $\mathrm{F}$ & PUD \\
\hline H1 & + & - & - & M & G \\
\hline $\mathrm{H} 2$ & + & + & + & $\mathrm{F}$ & $\mathrm{G}$ \\
\hline H3 & - & - & + & $\mathrm{M}$ & $\mathrm{G}$ \\
\hline $\mathrm{H} 4$ & + & - & + & $\mathrm{F}$ & G \\
\hline H5 & + & - & - & $\mathrm{M}$ & $\mathrm{G}$ \\
\hline H6 & + & + & + & M & PUD \\
\hline H7 & + & - & - & $\mathrm{F}$ & $\mathrm{G}$ \\
\hline H8 & + & - & + & M & G \\
\hline
\end{tabular}

( $\operatorname{cag} A)$ : cytotoxin-associated gene. (iceA1): induced by contact with epithelium allele A1. (iceA2): induced by contact with epithelium allele A2. (+): Positive. (-) :

Negative. (M): Male. (F):Female. (PUD): Peptic Ulcer Disease. $(\mathrm{G})$ : Gastritis.

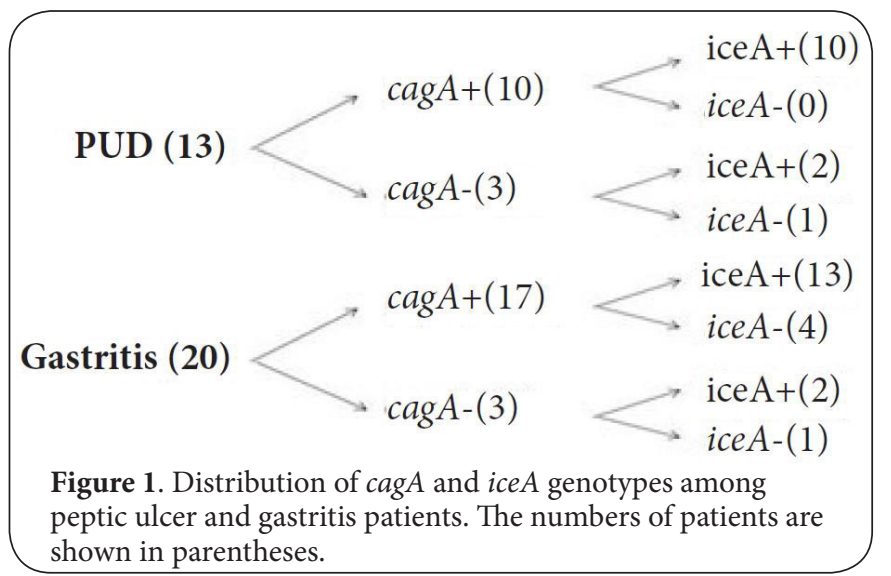

outcomes ( $p=0.658)$. There was also no association between $\operatorname{cag} A+$ and cagA- genotypes and gender of patients $(p=0.070)$. Likewise, 27 cases (81.7\%) were iceAt, while 6 cases (18.8\%) were iceA- by PCR. The percentage of iceA+ genotypes were $92.3 \%(12 / 13)$ and $75 \%(15 / 20)$ for PUD and gastritis cases, respectively. The percentage of iceA+ genotype within each clinical outcome was significantly higher than that of iceA- genotype. The percentages of iceA+ genotype differed significantly between the two clinical outcomes, as iceA+ genotype was detected more frequently in PUD patients as compared with gastritis patients. As with cagA gene, there was no association between ice $A$ genotypes and gender of patients.

In the current study, $93.9 \%$ (31/33 cases) of H. pylori positive specimens had at least one of the two virulence genes examined in this study, i.e., cagA and/or iceA (Figure 1). This suggests that the majority of $H$. pylori isolates examined in this study had virulence potential as evidenced by PCR-based molecular testing.

The prevalence of the combined cagA and iceA genotypes among the 13 peptic ulcer and 20 gastritis cases is shown in Figure 1. The percentage of cagA+/iceA+ genotype was significantly high $(p<0.001)$ within peptic ulcer $(76.9 \%)$ and also within gastritis $(65 \%)$ cases. However, no association was revealed between the prevalence of the four genotypes $(++,+-,-+,--)$ and the clinical outcome by using $2 \times 4$ Fisher's exact test $(p=0.498)$. Figure 1 shows that all of the cagA+H. pylori specimens $(n=10)$ that were typed from peptic ulcer cases were also found to have the iceA+ genotype. Of the $17 \mathrm{cag} A+H$. pylori specimens that were typed from gastritis patients, 13 specimens had the ice $A+$ genotype. The cagA+ genotype, therefore, could be a predictive marker for the $i c e A+$ genotype in $H$. pylori specimens isolated from peptic ulcer patients. This association was not observed within $H$. pylori specimens typed from gastritis cases.

The occurrence of ice $A 1$ and iceA2 double positive genotypes within the studied samples are shown in Table 2. Out of the 33 samples examined 19 (58\%) were double positive for iceA 1 and ice $A 2$ genes. These ice $A 1$ and ice $A 2$ double positives were found in 11 PUD $(11 / 13=85 \%)$ and 8 gastritis $(8 / 20=40 \%)$ cases. Table 2 shows also that cagA/iceA1/iceA2 positives occurred in $77 \%$ (10/13 cases) of PUD cases and in only $40 \%(8 / 20$ cases) of gastritis cases. There was a significant association between the occurrence ice $A 1$ and ice $A 2$ double positives and PUD ( $p=0.0188)$. Thus, it appears that infection with multiple strains of $H$. pylori occurs more frequently in patients with PUD, compared to those with gastritis.

\section{Discussion}

Our study determined the cagA and iceA geneotype of $H$. pylori biopsy samples in a group of patients attending the endoscopy clinic at Al-Hada Armed Forces Hospital, King Faisal Hospital, and King Abdul Aziz Hospital.

In this study, PCR was used to characterize $H$. pylori infections 
Kadi et al. Microbiology Discovery 2014,

Table 2. Occurrenceof iceA1/iceA2 double positives among all cases studied.

\begin{tabular}{|c|c|c|c|}
\hline \multicolumn{4}{|c|}{ PUD and Gastritis cases $(n=33)$ : } \\
\hline & $\operatorname{cag} A+$ & $\operatorname{cag} A-$ & Total \\
\hline iceAl & 0 & $1(3 \%)$ & $1(3 \%)$ \\
\hline iceA2 & $5(15 \%)$ & $2(6.0 \%)$ & $7(21 \%)$ \\
\hline iceA1/iceA2 & $18(54.5 \%)$ & $1(3 \%)$ & $19(57.5 \%)$ \\
\hline$i c e A-$ & $4(12 \%)$ & $2(6 \%)$ & $6(18 \%)$ \\
\hline Total & $27(81.8 \%)$ & $6(18 \%)$ & $33(100 \%)$ \\
\hline \multicolumn{4}{|c|}{ PUD cases $(n=13)$ : } \\
\hline & $\operatorname{cagA+}$ & $\operatorname{cag} A-$ & Total \\
\hline iceA1 & 0 & 0 & 0 \\
\hline iceA2 & 0 & $1(8 \%)$ & $1(8 \%)$ \\
\hline iceA1/iceA2 & $10(77 \%)$ & $1(8 \%)$ & $11(85 \%)$ \\
\hline iceA- & 0 & $1(8 \%)$ & $1(8 \%)$ \\
\hline Total & $10(77 \%)$ & $3(23 \%)$ & $13(100 \%)$ \\
\hline \multicolumn{4}{|c|}{ Gastritis cases $(n=20)$ : } \\
\hline & $\operatorname{cagA+}$ & $\operatorname{cag} A-$ & Total \\
\hline iceA1 & 0 & $1(5 \%)$ & $1(5 \%)$ \\
\hline ice $A 2$ & $5(25 \%)$ & $1(5 \%)$ & $6(30 \%)$ \\
\hline iceA1/iceA2 & $8(40 \%)$ & 0 & $8(40 \%)$ \\
\hline iceA- & $4(20 \%)$ & $1(5 \%)$ & $5(25 \%)$ \\
\hline Total & $17(85 \%)$ & $3(15 \%)$ & $20(100 \%)$ \\
\hline
\end{tabular}

in biopsy specimens and to examine the association between genotypes and clinical outcomes. The cytotoxin associated gene $\mathrm{A}$ (cagA gene) has been proposed as a marker for a genomic pathogenicity island (cag-PAl) of approximately 40 $\mathrm{kbp}$ whose presence is associated with more severe clinical outcomes $[\mathbf{2 8}, \mathbf{2 9}]$. The induced by contact with epithelium gene (iceA gene) has recently been discovered [20]. The two main allelic variants of the gene are ice $A 1$ and iceA2. The expression of iceA1 is upregulated on contact between $H$. pylori and human epithelial cells, and may be associated with peptic ulcer disease [24,30-31]. The results of the current study indicated that $93.9 \%$ of $H$. pylori isolates examined had at least one of these two virulence genes as evidenced by PCR-based molecular testing. These results were in agreement with that obtained by [32].

Our data indicated that the incidence of $H$. pylori-related diseases has been observed to be similar among men and women and no statistically significant difference in prevalence based on gender. However $[33,34]$, reported that the rate of infection with $H$. pylori, afflict men more frequently than women studied among 556 African-Americans. In a study reported by [35] the prevalence rate among males (18.9\%) was significantly higher $(p<0.001)$ than that among females $(9.0 \%)$.

The cagA gene was detected in $81.8 \%(27 / 33)$ of recovered H. pylori specimens which is similar to other countries $[36,37]$.
The frequency of cagA gene was reported to be around $62 \%$ in a Saudi study [38] compared to 70\% in Europe, 85\% in Estonian and Russia, 90\% in East Asia [39] and 63\% in Japan [40]. The percentage of cagA+ genotype within each clinical outcome was significantly higher than that of cagA- genotype $(p<0.001)$. However, the prevalence of cagA+ and cagA- genotypes did not differ significantly between the two clinical outcomes $(p=0.658)$.

Likewise, the iceA gene was detected in $81.7 \%$ (27/33), while 6 cases $(18.8 \%$ ) were iceA- by PCR (Figure 1 ). The percentage of iceA+ genotypes were $92.3 \%(12 / 13)$ and $75 \%$ (15/20) for PUD and gastritis cases, respectively. The percentage of iceA+ genotype within each clinical outcome was significantly higher than that of iceA- genotype. The percentages of iceAt genotype differed significantly between the two clinical outcomes, as ice A+ genotype was detected more frequently in PUD patients as compared with gastritis patients. As with cagA gene, there was no association between ice $A$ genotypes and gender of patients.

In a study reported by [41] found that $87.4 \%$ of the positive $H$. pylori cases were iceA2 positive compared to only $12.6 \%$ cases positive for iceA1. As reported by $[42,43]$ iceA 1 expression is associated with a higher activity of the gastric inflammation, a condition that increases the risk for developing ulcer disease and gastric carcinoma.

Previous studies in the United States andthe Netherlands have demonstrated a strong association between ice $A 1$ and ulcer disease which also proved by $[30,31,41]$.

The prevalence of the combined cagA and iceA genotypes among the 13 peptic ulcer and 20 gastritis cases is shown in Figure 1. The percentage of cagA+/ice $A+$ genotype was significantly high $(p<0.001)$ within peptic ulcer $(76.9 \%)$ and also within gastritis (65\%) cases. However, no association was revealed between the prevalence of the four genotypes (+ $+,+-,-+,--)$ and the clinical outcome by using $2 \times 4$ Fisher's exact test $(p=0.498)$. Figure 1 shows that all of the cagA+H. pylori specimens $(n=10)$ that were typed from peptic ulcer cases were also found to have the iceA+ genotype. Of the $17 \mathrm{cag} A+H$. pylori specimens that were typed from gastritis patients, 13 specimens had the iceA+ genotype. The cagA+ genotype, therefore, could be a predictive marker for the iceA+ genotype in $\mathrm{H}$. pylori specimens isolated from peptic ulcer patients. This association was not observed within $H$. pylori specimens typed from gastritis cases.

The occurrence iceA 1 and iceA 2 double positive genotypes within the studied samples are shown in Table 2. Out of the 33 samples examined 19 (58\%) were double positive for iceA1 and ice $A 2$ genes. These double positives were found in 10 PUD $(11 / 13=77 \%)$ and 8 gastritis $(8 / 20=40 \%)$ cases. Thus, it appears that infection with multiple strains of $H$. pylori occurs more frequently in patients with PUD, compared to those with gastritis. Out of the 19 ice $A 1$ and iceA2 double positive samples, 18 samples had the cagA+ genotype. Table 2 shows that cagA+/iceA1/iceA2 double positive genotypes occurred 
Kadi et al. Microbiology Discovery 2014,

in $77 \%$ of PUD cases and in only $40 \%$ of gastritis cases.

These results are in agreement with those reported by [33] who found a high correlation between the iceA1+ and peptic ulcer disease. Also as reported by [39], all the ulcer cases (100 $\%)$ were iceA1 positive with statistically significant correlation ( $p=0.0001)$, while iceA1 allele was found in $94.6 \%$ of gastritis cases. Other studies from Asia suggested no association between cagA \& iceA genotypes and peptic ulcer disease [44]. As investigated by [45] H. pylori genotypes are not equally distributed all over the world.

In conclusion, PCR- based genotyping should be done for high-risk patients who are infected with multi genotypes of H. pylori in order to prevent the development of ulcer and cancer diseases later in their life.

\section{Competing interests}

The authors declare that they have no competing interests.

Authors' contributions

\begin{tabular}{|l|c|c|c|}
\hline Authors' contributions & RHK & EMH & HSA \\
\hline Research concept and design & $\checkmark$ & $\checkmark$ & $\checkmark$ \\
\hline Collection and/or assembly of data & $\checkmark$ & $\checkmark$ & $\checkmark$ \\
\hline Data analysis and interpretation & $\checkmark$ & $\checkmark$ & $\checkmark$ \\
\hline Writing the article & $\checkmark$ & $\checkmark$ & $\checkmark$ \\
\hline Critical revision of the article & -- & $\checkmark$ & $\checkmark$ \\
\hline Final approval of article & -- & $\checkmark$ & $\checkmark$ \\
\hline Statistical analysis & -- & $\checkmark$ & $\checkmark$ \\
\hline
\end{tabular}

Acknowledgement

This work was supported by Taif University and A grant from the Applied Research Program-Graduate Students, King AbdulAziz for Science and Technology, Riyadh. MSc. Contract $n^{\circ}: 1000-12$. Our thanks go to the Ministry of Health hospitals in Saudi Arabia for providing us with gastric biopsy specimens.

Publication history

Editor: Lisa Durso, United States Department of Agriculture, USA. EIC:Todd R. Callaway, Food and Feed Safety Research Unit, USA. Received: 08-Aug-2013 Revised: 07-Sep-2013

First Re-Revised: 22-Jan-2014 Finial Re-Revised: 01-Feb-2014 Accepted: 11-Feb-2014 Published: 17-Feb-2014

\section{References}

1. Peek RM, Jr. and Blaser MJ. Helicobacter pylori and gastrointestinal tract adenocarcinomas. Nat Rev Cancer. 2002; 2:28-37. I Article I PubMed

2. Suerbaum $S$ and Michetti P. Helicobacter pylori infection. N Engl J Med. 2002; 347:1175-86. | Article

3. Cavaleiro-Pinto $\mathrm{M}$, Peleteiro $\mathrm{B}$, Lunet $\mathrm{N}$ and Barros $\mathrm{H}$. Helicobacter pylori infection and gastric cardia cancer: systematic review and metaanalysis. Cancer Causes Control. 2011; 22:375-87. I Article I PubMed

4. Ho SA, Hoyle JA, Lewis FA, Secker AD, Cross D, Mapstone NP, Dixon MF, Wyatt JI, Tompkins DS, Taylor GR and et al. Direct polymerase chain reaction test for detection of Helicobacter pylori in humans and animals. J Clin Microbiol. 1991; 29:2543-9. | Article | PubMed Abstract | PubMed Full Text

5. Hammar M, Tyszkiewicz T, Wadstrom T and O'Toole PW. Rapid detection of Helicobacter pylori in gastric biopsy material by polymerase chain reaction. J Clin Microbiol. 1992; 30:54-8. | Article | PubMed Abstract | PubMed Full Text
6. Liu H, Rahman A, Semino-Mora C, Doi SQ and Dubois A. Specific and sensitive detection of $\mathrm{H}$. pylori in biological specimens by real-time RT-PCR and in situ hybridization. PLoS One. 2008; 3:e2689. | Article | PubMed Abstract | PubMed Full Text

7. Rimbara E, Sasatsu M and Graham DY. PCR detection of Helicobacter pylori in clinical samples. Methods Mol Biol. 2013; 943:279-87. | Article I PubMed

8. Menoni SM, Bonon SH, Zeitune JM and Costa SC. PCR-Based Detection and Genotyping of Helicobacter pylori in Endoscopic Biopsy Samples from Brazilian Patients. Gastroenterol Res Pract. 2013; 2013:951034. | Article | PubMed Abstract | PubMed Full Text

9. Goodman KJ and Correa P. Transmission of Helicobacter pylori among siblings. Lancet. 2000; 355:358-62. | Article | PubMed

10. Glynn MK, Friedman CR, Gold BD, Khanna B, Hutwagner L, lihoshi N, Revollo $C$ and Quick R. Seroincidence of Helicobacter pylori infection in a cohort of rural Bolivian children: acquisition and analysis of possible risk factors. Clin Infect Dis. 2002; 35:1059-65. | Article I PubMed

11. Hussein NR, Napaki SM and Atherton JC. A study of Helicobacter pyloriassociated gastritis patterns in Iraq and their association with strain virulence. Saudi J Gastroenterol. 2009; 15:125-7. | Article | PubMed Abstract | PubMed Full Text

12. Fakhro AR, Fateha Bel D, Amin Farid IM and Jamsheer HM. The association between Helicobacter pylori infection and lymphoid reaction in patients suffering from dyspepsia in Bahrain. Saudi J Gastroenterol. 1999; 5:129-33. I Article I PubMed

13. Nimri LF, Matalka I, Bani Hani K and Ibrahim M. Helicobacter pylori genotypes identified in gastric biopsy specimens from Jordanian patients. BMC Gastroenterol. 2006; 6:27. | Article | PubMed Abstract | PubMed Full Text

14. Al Qabandi A, Mustafa AS, Siddique I, Khajah AK, Madda JP and Junaid TA. Distribution of vacA and cagA genotypes of Helicobacter pylori in Kuwait. Acta Trop. 2005; 93:283-8. I Article I PubMed

15. Mahmoud RAK, Morcos HH, Hegazi AA, Abo Seif MA and ElHadidy KS. The serological gastric biopsy: a non-endoscopical/histopathologic diagnostic approach in management of the dyspeptic patients. Am J Immunol. 2006; 2:88-96. | Article

16. Ayoola AE, Ageely HM, Gadour MO and Pathak VP. Prevalence of Helicobacter pylori infection among patients with dyspepsia in SouthWestern Saudi Arabia. Saudi Med J. 2004; 25:1433-8. I Article I PubMed

17. BinSaeed AA. Glimpse of the epidemiological research on Helicobacter pylori in Saudi Arabia. Saudi J Gastroenterol. 2009; 15:85. | Article | PubMed Abstract I PubMed Full Text

18. Martins LC, Corvelo TC, Demachki S, Araujo MT, Assumpcao MB, Vilar SC, Freitas FB, Barbosa HP, Fecury AA, do Amaral RK and Dos Santos SE. Clinical and pathological importance of vacA allele heterogeneity and cagA status in peptic ulcer disease in patients from North Brazil. Mem Inst Oswaldo Cruz. 2005; 100:875-81. | Article | PubMed

19. Rizzato C, Torres J, Plummer M, Munoz N, Franceschi S, CamorlingaPonce M, Fuentes-Panana EM, Canzian F and Kato I. Variations in Helicobacter pylori cytotoxin-associated genes and their influence in progression to gastric cancer: implications for prevention. PLoS One. 2012; 7:e29605. | Article | PubMed Abstract | PubMed Full Text

20. Arevalo-Galvis A, Trespalacios-Rangell AA, Otero W, Mercado-Reyes MM and Poutou-Pinales RA. Prevalence of cagA, vacA, babA2 and ice A genes in $\mathrm{H}$. pylori strains isolated from Colombian patients with functional dyspepsia. Pol J Microbiol. 2012; 61:33-40. I Pdf I PubMed

21. Zhou J, Zhang J, Xu C and He L. cagA genotype and variants in Chinese Helicobacter pylori strains and relationship to gastroduodenal diseases. J Med Microbiol. 2004; 53:231-5. | Article I PubMed

22. Proenca-Modena JL, Acrani GO and Brocchi M. Helicobacter pylori: phenotypes, genotypes and virulence genes. Future Microbiol. 2009; 4:223-40. | Article | PubMed

23. Shiota S, Watada M, Matsunari O, Iwatani S, Suzuki R and Yamaoka Y. Helicobacter pylori iceA, clinical outcomes, and correlation with cagA: a meta-analysis. PLoS One. 2012; 7:e30354. | Article | PubMed Abstract | PubMed Full Text 
Kadi et al. Microbiology Discovery 2014,

24. Yamaoka Y, Kodama T, Gutierrez O, Kim JG, Kashima K and Graham DY. Relationship between Helicobacter pylori iceA, cagA, and vacA status and clinical outcome: studies in four different countries. J Clin Microbiol. 1999; 37:2274-9. | Article | PubMed Abstract | PubMed Full Text

25. Ando T, Peek RM, Pride D, Levine SM, Takata T, Lee YC, Kusugami K, van der Ende A, Kuipers EJ, Kusters JG and Blaser MJ. Polymorphisms of Helicobacter pylori HP0638 reflect geographic origin and correlate with cagA status. J Clin Microbiol. 2002; 40:239-46. | Article I PubMed Abstract | PubMed Full Text

26. Yamaoka Y, Orito E, Mizokami M, Gutierrez O, Saitou N, Kodama T, Osato MS, Kim JG, Ramirez FC, Mahachai V and Graham DY. Helicobacter pylori in North and South America before Columbus. FEBS Lett. 2002; 517:1804. | Article | PubMed

27. Ashour AA, Collares GB, Mendes EN, de Gusmao VR, Queiroz DM, Magalhaes PP, de Carvalho AS, de Oliveira CA, Nogueira AM, Rocha GA and Rocha AM. iceA genotypes of Helicobacter pylori strains isolated from Brazilian children and adults. J Clin Microbiol. 2001; 39:1746-50. | Article I PubMed Abstract | PubMed Full Text

28. Blaser MJ, Perez-Perez GI, Kleanthous H, Cover TL, Peek RM, Chyou $\mathrm{PH}$, Stemmermann GN and Nomura A. Infection with Helicobacter pylori strains possessing cagA is associated with an increased risk of developing adenocarcinoma of the stomach. Cancer Res. 1995; 55:21115. I PubMed

29. Atherton JC. CagA: a role at last. Gut. 2000; 47:330-1. | Article

30. Van Doorn LJ, Figueiredo C, Sanna R, Plaisier A, Schneeberger P, de Boer $W$ and Quint W. Clinical relevance of the cagA, vacA, and ice $A$ status of Helicobacter pylori. Gastroenterology. 1998; 115:58-66. | Article | PubMed

31. Peek RM, Jr., Thompson SA, Donahue JP, Tham KT, Atherton JC, Blaser MJ and Miller GG. Adherence to gastric epithelial cells induces expression of a Helicobacter pylori gene, iceA, that is associated with clinical outcome. Proc Assoc Am Physicians. 1998; 110:531-44. | Article | PubMed

32. Taylor NS, Fox JG, Akopyants NS, Berg DE, Thompson N, Shames B, Yan $L$, Fontham E, Janney F, Hunter FM and et al. Long-term colonization with single and multiple strains of Helicobacter pylori assessed by DNA fingerprinting. J Clin Microbiol. 1995; 33:918-23. | Article I PubMed Abstract | PubMed Full Text

33. Replogle ML, Glaser SL, Hiatt RA and Parsonnet J. Biologic sex as a risk factor for Helicobacter pylori infection in healthy young adults. Am J Epidemiol. 1995; 142:856-63. | Article | PubMed

34. Matsukura N, Onda M, Kato S, Hasegawa H, Okawa K, Shirakawa T, Tokunaga A, Yamashita K and Hayashi A. Cytotoxin genes of Helicobacter pylori in chronic gastritis, gastroduodenal ulcer and gastric cancer: an age and gender matched case-control study. Jpn J Cancer Res. 1997; 88:532-6. | Article | PubMed

35. Sasidharan S, Lachumy SJ, Ravichandran M, Latha LY and Gegu SR. Epidemiology of Helicobacter pylori among multiracial community in Northern Peninsular, Malaysia: effect of age across race and gender. Asian Pac J Trop Med. 2011; 4:72-5. | Article | PubMed

36. WGO, World Gastroenterology Organization Global Guidelines. Helicobacter pylori in developing countries. 2010; 1-15. | Pdf

37. Adeniyi BA, Otegbayo JA, Lawal TO, Oluwasola AO, Odaibo GN and Samuel $\mathrm{CO}$ et al. Prevalence of Helicobacter pylori infection among dyspepsia patients in Ibadan, South West Nigeria. Afr J Microbiol Res. 2012; 6:3399-402. I Pdf

38. Marie MA. Relationship between Helicobacter pylori virulence genes and clinical outcomes in Saudi patients. J Korean Med Sci. 2012; 27:1903. I Article | PubMed Abstract | PubMed Full Text

39. Saribasak H, Salih BA, Yamaoka Y and Sander E. Analysis of Helicobacter pylori genotypes and correlation with clinical outcome in Turkey. J Clin Microbiol. 2004; 42:1648-51. | Article | PubMed Abstract | PubMed Full $\underline{\text { Text }}$

40. Hirai I, Sasaki T, Kimoto A, Fujimoto S, Moriyama T and Yamamoto Y. Assessment of East Asian-type cagA-positive Helicobacter pylori using stool specimens from asymptomatic healthy Japanese individuals. $J$ Med Microbiol. 2009; 58:1149-53. | Article | PubMed
41. Momenah AM and Tayeb MT. Helicobacter pylori cagA and iceA genotypes status and risk of peptic ulcer in Saudi patients. Saudi Med J. 2007; 28:382-5. | Article | PubMed

42. Ashour AA, Magalhaes PP, Mendes EN, Collares GB, de Gusmao VR, Queiroz DM, Nogueira AM, Rocha GA and de Oliveira CA. Distribution of vacA genotypes in Helicobacter pylori strains isolated from Brazilian adult patients with gastritis, duodenal ulcer or gastric carcinoma. FEMS Immunol Med Microbiol. 2002; 33:173-8. | Article | PubMed

43. Ben Mansour K, Fendri C, Zribi M, Masmoudi A, Labbene M, Fillali A, Ben Mami N, Najjar T, Meherzi A, Sfar T and Burucoa C. Prevalence of Helicobacter pylori vacA, cagA, ice $A$ and oipA genotypes in Tunisian patients. Ann Clin Microbiol Antimicrob. 2010; 9:10. | Article I PubMed Abstract | PubMed Full Text

44. Zheng PY, Hua J, Yeoh KG and Ho B. Association of peptic ulcer with increased expression of Lewis antigens but not cagA, ice $A$, and vacA in Helicobacter pylori isolates in an Asian population. Gut. 2000; 47:18-22. | Article | PubMed Abstract | PubMed Full Text

45. Van Doorn LJ, Figueiredo C, Megraud F, Pena S, Midolo P, Queiroz DM, Carneiro F, Vanderborght B, Pegado MD, Sanna R, De Boer W, Schneeberger PM, Correa P, Ng EK, Atherton J, Blaser MJ and Quint WG. Geographic distribution of vacA allelic types of Helicobacter pylori. Gastroenterology. 1999; 116:823-30. | Article | PubMed

Citation:

Kadi RH, Halawani EM and Abdelkader HS. Prevalence of $\mathrm{H}$. pylori strains harbouring cagA and iceA virulence genes in saudi patients with gastritis and peptic ulcer disease. Microbiol Discov. 2014; 2:2. http://dx.doi.org/10.7243/2052-6180-2-2 